\title{
Učbeniški komplet Grandi amici 1, 2, 3 za starostno obdobje 9-11 let
}

- G. Gerngross, H. Puchta, G. Rettaroli: Grandi amici 1, ELI, prva izdaja 2004

- G. Gerngross, H. Puchta, G. Rettaroli: Grandi amici 2, ELI, prva izdaja 2004 ;

- G. Gerngross, H. Puchta, G. Rettaroli: Grandi amici 3, ELI, prva izdaja 2004)

\section{Uvod}

Grandi amici 1 je namenjen osnovnošolskim otrokom, in sicer začetni stopnji učenja italijanščine, Ob bežnem prelistanju opazimo, da je ta didaktični komplet izrazito bogat $\mathrm{z}$ raznoliko kombinacijo fotografij (otroci različnih ras, $\mathrm{v}$ starostnem obdobju 8-10 let) in ilustracij (protagonisti v učbeniku, npr. tiger Tobi, čarovnička Lillo, drugi otroci, živali, stvari, stripi) - vse naj bi pritegnilo učenca in učitelja v raznoliki svet otrok v obdobju tik pred pričetkom najstništva.

Navedene protagoniste učenec zagleda že na platnicah, v ozadju so fotografije italijanskih znamenitosti. Na prvi notranji strani platnic je nazoren politični zemljevid Italije $\mathrm{z}$ dvajsetimi regijami in njihovimi glavnimi mesti. Žal pa je zemljevid sosednjih držav pomanjkljiv: v njem ni Istre in Kvarnerskega zaliva (pa tudi ne Korzike), kar bo potrebno zlasti v 5. razredu pri pouku ustrezno dopolniti..

Barvne oznake posameznih učnih enot in njihovih delov so jasne: na enak način vsak del učne enote, ki obravnava isto temo (praviloma 1 $\mathrm{x}$ ali 2 x po 2 sosednji strani); sprememba v barvni oznaki robov pomeni spremembo teme. Besedila so tipografsko zelo dobro berljiva.

\section{Sestava učbeniškega kompleta Grandi amici 1, 2, 3}

\section{- učbenik}

(vključno z uvodno po 11 učnih enot, vmes so 3 enote za samopreverjanje: po 4., po 7. in po 10. učni enoti, na koncu učbenika pa še pri » «3 kratki sklopi o ital. praznikih (Božič, la Befana, Velika noč), zatem 'scenarij' za musical, slikovna italijanska abeceda oz. pri »2« na koncu 
učbenika je še 1 nekoliko daljši skeč oz. pri »3« ????

in Dodatek / Appendice s posrečeno kombinacijo glosarja, nabora

sporazumevalnih vzorcev in prikaz drobnih 'slovničnih' posebnosti z zgolj funkcionalnimi nameni (brez metajezikovnega izrazoslovja);

- CD s slušnimi besedili, ki dopolnjujejo »učbeniške / šolske« učne enote: vsa besedila in navodila v učbeniku lahko učenci slišijo prek

CDja;

- priročnik za učitelja;

- delovni zvezek;

- (možna je nabava DVD-ja s stripi Dieci storie da mimare).

\section{Učbenik, format A5}

Celoten učbenik obsega 95 strani, vse v barvnem tisku. Namenjen je aktivni uporabi, tj. učenci vanj pišejo. Uvodno kazalo vsebuje naslove glavne teme $\mathrm{v}$ posamični učni enoti. $\mathrm{V}$ učbeniškem delu je uvodna učna enota in še 10 nadaljnjih, ki jim je namenjeno po 6 strani. Teme so del sveta 8-10 letnih otrok (in marsikatera je primerna tudi za medpredmetno povezovanje: npr. glasbena vzgoja, likovni pouk, okoljska vzgoja, spoznavanje okolja, matematika): 


\begin{tabular}{|c|c|c|}
\hline $\begin{array}{l}\text { Grandi amici } 1 \\
\text { uvodna enota: } \\
\text { pozdravimo se in } \\
\text { predstavimo se drug } \\
\text { drugemu } \\
\text { 1. enota: številke } \\
\text { 2. enota: barve } \\
\text { 3. enota: v šoli } \\
\text { 4. enota: najljubše živali } \\
\text { samopreverjanje / } \\
\text { autovalutazione } \\
\text { 5. enota: dnevi v tednu } \\
\text { 6. enota: oblačila } \\
\text { 7. enota: rojstni dan } \\
\text { samopreverjanje / } \\
\text { autovalutazione } \\
\text { 8. enota: počutje in } \\
\text { čustva } \\
\text { 9. enota: najljubša hrana } \\
\text { 10. enota: telo } \\
\text { samopreverjanje / } \\
\text { autovalutazione } \\
\text { dodatne enote: il Natale, } \\
\text { la Befana, la Pasqua } \\
\text { musical: družina, odhod } \\
\text { na morje/plažo, 'darilo' } \\
\text { z odpadki } \\
\text { (okoljevarstveni } \\
\text { zaključek) }\end{array}$ & $\begin{array}{l}\text { Grandi amici } 2 \\
\text { uvodna enota: ponovno } \\
\text { snidenje } \\
\text { 1. enota: kje je kaj v } \\
\text { razredu } \\
\text { 2. enota: številke in cene } \\
\text { 3. enota: šolski predmeti; } \\
\text { slabo ravnanje z živalmi } \\
\text { 4. enota: prosti čas } \\
\text { samopreverjanje / } \\
\text { autovalutazione } \\
\text { 5. enota: koliko je ura? } \\
\text { 6. enota: prijatelji: kaj } \\
\text { znajo in kaj radi počnejo } \\
\text { 7. enota: živali } \\
\text { samopreverjanje / } \\
\text { autovalutazione } \\
\text { 8. enota: kaj imam v } \\
\text { svoji sobi } \\
\text { 9. enota: igranje, igre } \\
\text { 10. enota: pretekle in } \\
\text { prihodnje počitnice } \\
\text { samopreverjanje / } \\
\text { autovalutazione } \\
\text { dodatne enote: } 1 \text { skeč: } \\
\text { pica za babico }\end{array}$ & $\begin{array}{l}\text { Grandi amici } 3 \\
\text { uvodna enota: ponovno } \\
\text { snidenje } \\
\text { 1. enota: šolska žurka } \\
\text { (praznovanje) } \\
\text { 2. enota: amuleti, za } \\
\text { srečo } \\
\text { 3. enota: sanje } \\
\text { 4. enota: kaj zbiraš? } \\
\text { samopreverjanje / } \\
\text { autovalutazione } \\
\text { 5. enota: šolski predmeti, } \\
\text { urnik } \\
\text { 6. enota:živeti v hribih } \\
\text { 7. enota: televizija } \\
\text { samopreverjanje / } \\
\text { autovalutazione } \\
\text { 8. enota: v mestu } \\
\text { 9. enota: dogodivščine, } \\
\text { strah me je ... } \\
\text { 10. enota: ob morju } \\
\text { samopreverjanje / } \\
\text { autovalutazione } \\
\text { dodatne enote: } \\
\text { 6 skečev: princeska in } \\
\text { žaba, maska, gremo na } \\
\text { plažo, } \\
\text { rojstnodnevno darilo, } \\
\text { Sandra, telefonski } \\
\text { razgovor }\end{array}$ \\
\hline
\end{tabular}

Večina učnih enot vsebuje uvodoma ali drugje $\mathrm{v}$ lekciji po (najmanj) 1 ritmizirano besedilo za petje ali recitiranje (pesmico, izštevanko ipd.), ki ga spremljajo naloge za spoznavanje in utrjevanje besedišča.

Zatem najpogosteje sledi osrednji del lekcije s stripom (tematska zgodbica $\mathrm{v}$ stripu), ki jo učenci poslušajo: $\mathrm{v}$ večini učnih enot so 
povabljeni, da ob poslušanju posnemajo gibanje protagonista na sličicah, zatem pa jo lahko tudi zaigrajo (posnemanje ali delno spreminjanje dialogov v stripu).

$\mathrm{V}$ zaključnem delu učne enote se pojavljajo praviloma naloge, ki spodbujajo učence $\mathrm{k}$ igranju kratkih govornih igric in/ali $\mathrm{k}$ personalizaciji novega besedišča (glede na obravnavano temo povej nekaj o sebi in/ali povprašaj sošolca).

Po 4., 7. in 10. učni enoti se pojavi 4-stranska enota za samopreverjanje (Verifica 1, 2, 3), kjer učenci ob risanju, povezovanju, izbiranju, obkroževanju ipd. ponovijo svoje (osnovno!) znanje predhodnih 3 učnih enot. Glede na starostno stopnjo učencev med nalogami NI eksplicitnih nalog za urjenje slovničnih struktur, slovnica je implicitna. Rešitve nalog so v Priročniku za učitelja.

Učbenik Grandi amici 1 zaključuje troje dvojnih strani o božičnonovoletnih in velikonočnih praznikih (il Natale, la Befana, la Pasqua) s tematskimi pesmicami in igricami, ter musical $s$ počitniško in okoljevarstveno vsebino; Grandi amici 2 zaključuje samo en daljši skeč, Grandi amici 3 pa zaključuje šest skečev.

Na koncu vsakega učbenika je še razdelek Appendice, kjer ima učenec svoj mali priročni glosar po učnih enotah, v katerem so izrazi urejeni abecedno. Različen barvni tisk $\mathrm{v}$ glosarju nudi slovnične informacije (npr. samostalniki moškega so modri, ženskega spola pa rdeči). Učenec si po potrebi sam označi pomen izraza v slovenščini. Povsem na koncu učbenika so še listi, ki jih učenec uporabi za igro (razreže, sestavi, prilepi v ustrezno učno enoto).

\section{Delovni zvezek, format A5}

Delovni zvezek obsega 31 strani, v rdeče-belem tisku (»1«) oz. v modrobelem tisku (»2«) oz. v zeleno-belem tisku (»3«). Vsaki učni enoti je namenjenih po 2-3 strani vaj, med katerimi prevladujejo naloge za ponavljanje oz. utrjevanje besedišča in razvijanje bralnega razumevanja, pa tudi za urjenje sporazumevalnih vzorcev (povezovanje in/ali dopolnjevanje dialogov) in celo zametki nalog za razvijanje pisnega sporočanja (sestavljanje, dopolnjevanje, urejanje krajših besedil). 
V nalogah lahko učenci barvajo, rišejo in razvozlavajo simbolično pisavo, s čimer izkazujejo svoje bralno razumevanje. Se razume, da glede na starostno stopnjo učencev med nalogami NI eksplicitnih nalog za urjenje slovničnih struktur, slovnica je povsem implicitna v (»1«), in ostane (skoraj popolnoma) implicitna $\mathrm{v} » 2$ « in $\mathrm{v} » 3$ «. Rešitve nalog $\mathrm{v}$ delovnem zvezku so le v Priročniku za učitelja.

V 4. in 5. razredu, oz. pri starosti 9-10-11 let bi učencem in učitelju prišel prav že postopoma bolj obširen delovni zvezek, ob katerem bi se lahko zagotovilo zares dovolj ponavljanja in utrjevanja snovi. Priporoča se, da učitelji poiščejo in/ali izdelajo dodatne naloge za domače delo učencev.

\section{CD k učbeniku}

Slušna besedila so zelo številna, primerno dolga, dobro slišna in razločna, izgovor in intonacija sta ustrezna. Za učitelja velja omeniti tudi, da zvočna besedila v učbeniku niso označeno z zaporedno številko zapisa na CDju, zato si jih je smiselno napisati ob naloge. Transkripcije vseh besedil na CDju so vključene v predstavitve (možnih) didaktizacij vsake posamične učne enote v Priročniku za učitelja.

Ravno glasbena plat CD-ja je bistvena prednost tega učbeniškega kompleta: izjemna muzikaličnost, raznovrstnost melodij in ritmov, v kombinaciji s smiselnimi vsebinami za to starostno obdobje - vse to bo zagotovo lahko delovalo pri pouku zelo spodbudno!

\section{Priročnik za učitelja, format A5}

Uvodoma je na prvih 9 straneh izčrpno predstavljen koncept učbeniškega kompleta, namen in vloga njegovih posamičnih delov, vključno z nalogami v delovnem zvezku (Libro degli esercizi). Sledi Sillabo na 2 straneh: izčrpen prikaz vsebine po učnih enotah: teme, jezikovne funkcije, strukture, besedišče, navedba dejavnosti za vsako posamično učeno enoto. Iz prikaza lahko učitelj dobi vpogled v slovnične strukture, ki tvorijo 'prikrito', implicitno slovnico tega učbenika.

Zatem je za vsako učno enoto navedena tema, kaj se bodo učenci naučili razumeti (receptivno znanje), kaj se bodo naučili uporabljati (produktivno znanje), ter povzetek operativnih ciljev. Sledijo izčrpni, vendar kratki, praktični in koncizni napotki za didaktizacijo vsakega 
dela učne enote, po korakih za vsako dejavnost. V korake so sproti vključeni tudi zapisi slušnih besedil in rešitve nalog (opis možnih didaktizacij najdemo tudi za učne enote za preverjanje znanja in tematske zaključne učne enote na koncu učbenika).

Na koncu priročnika za učitelja so zbrane tudi rešitve za naloge iz delovnega zvezka, sledi pa še 7 strani ilustracij, ki tematsko dopolnjujejo dejavnosti v določenih učnih enotah: učitelj jih lahko razdeli učenem kot črnobele fotokopije, da jih pobarvajo, razrežejo, prilepijo ipd.

\section{Besedišče}

Vsaka učna enota ima svojo vodilno temo (gl. teme pri opisu zgradbe učbenika), ki se v vsaki učni enoti nekoliko razveja, v naslednjih učnih enotah pa ciklično ponavlja. $Z$ besediščnimi sklopi se učenci srečujejo $\mathrm{v}$ pesmicah in pri drugih nalogah (predvsem povezovanje med sliko ali fotografijo in besedami) ter $\mathrm{v}$ kratkih besedilih za bralno razumevanje. Naloge za obravnavanje besedišča so razporejene tako v učbeniku kot delovnem zvezku, predvidene pa tudi v okviru dodatnih fotokopiranih izročkov iz Priročnika za učitelja.

\section{Slovnica}

Na tej starostni stopnji je vsako eksplicitno obravnavanje slovničnih struktur neustrezno, prav pa je, da učitelj ve, katere slovnične oz. jezikovne strukture so predmet urjenja na nezavedni ravni. Učbenik vsebuje (skoraj popolnoma oz. pretežno) implicitno uporabo številnih osnovnih jezikovnih oz. slovničnih struktur. Posrečene in učinkovite bodo najverjetneje tiste komunikacijske (in v njih slovnične) strukture, ki so vključene v besedila, ki jih učenci pojejo ali recitirajo, še zlasti, če bo učitelj vztrajal, da se jih trajno naučijo, npr. tudi $\mathrm{z}$ domačim ponavljanjem.

Neke vrste slovnični pregled za učenca so tabelice, vključene $\mathrm{v}$ glosarje po učnih enotah, ki se nahajajo na koncu učbenika, v Appendice. Učitelj pa ima vpogled $\mathrm{v}$ implicitno vključene slovnične in jezikovne strukture v uvodnem pregledu (Sillabo) v Priročniku za učitelja.

V koliko se bo učitelj v 4. in 5. razredu vendarle postopoma odločil tudi za občasno zavestno (eksplicitno) obravnavanje slovničnih struktur, bodo verjetno zadostovala zgolj kratka pojasnila vsebine okvirčkov 
(najbolj priporočljivo $\mathrm{v}$ slovenščini, brez odvečnih metajezikovnih izrazov, zgolj v skladu $s$ tovrstnim znanjem v slovenščini). Priporoča se tudi uporaba primerne pedagoške slovnice, ustrezne za to starostno obdobje (8-9-10 let), , ali celo take, ki jo bodo lahko uporabljali do 14 . leta.

Ocena skladnosti učnega gradiva s sodobnimi spoznanji strok, ki opredeljujejo predmet oz. področje

$\mathrm{V}$ učbeniku in delovnem zvezku je princip poučevanja in učenja na nezavednemu usvajanju jezika (razumevanju, tekočnosti izražanja, prikritemu in/ali vodenemu posnemanju jezikovnih vzorcev in celih kratkih besedil): gre za principe učinkovitih tehnik komunikacijskega pristopa pri tej starostni stopnji.

Metodološka zasnovanost učnih enot teži k razvijanju slušnega in bralnega razumevanja, ter k spoznavanju in urjenju besedišča. Besedila znotraj posamičnih enot so vsebinsko raznolika, vendar ostajajo povsem blizu okvirne teme, tako da se učenci ne soočajo s pretiranim razraščanjem količine besedišča (kar lahko pri učenju jezika učinkuje tudi zaviralno).

Besedila spremlja bogato slikovno gradivo: v večini gre za ilustracije, precej je tudi fotografij otrok, sovrstnikov učencev. Kombinacija besedilnega in slikovnega je zanimiva in privlačna: ta pestrost naj bi spodbujala učenca k aktivnemu odnosu do učenja jezika. Učbenik nudi možnosti za različne oblike dela, poleg dela v dvojicah in/ali skupinah bi še posebej izpostavila možnost dramatizacije stripov z razdelitvijo vlog med več učencev (enako velja tudi za musical in skeče).

Učenci implicitno spoznajo, razumejo in/ali dopolnjujejo različne zvrsti besedil (krajši dialogi, kratka opisna besedila, različna usmerjevalna/regulativna besedila). Morda nekoliko primanjkuje spodbud, da bi učenci po zgledu obravnavnih besedil tvorili svoja besedila: odločitev za usmerjene učencev $\mathrm{v}$ (po)ustvarjanje besedil je torej precej odvisna od odločitve učitelja, vsekakor naj bi vsaj boljši učenci dobili njegovo spodbudo pri zahtevnejših dejavnostih te vrste.

Avtorji prepuščajo raven uporabe materinščine uporabnikom, učenci so nanjo implicitno napoteni pri lastnem dopolnjevanju 
slovarčka, učitelji pa jo bodo uporabili po svoji presoji (npr. pri kratkih slovničnih pojasnilih, pri besedišču, ki ne more biti ilustrirano ipd.).

\title{
Sklepne misli
}

Iz doslej navedenega je razvidno, da je Grandi amici 1, 2, 3 skladen s sodobnimi predmetno-didaktičnimi spoznanji: gre za komunikacijsko zasnovano učno gradivo, s poudarki na razvijanju štirih spretnosti in značilnih sporazumevalnih vzorcev. Zdi se smiselno, da učitelj $\mathrm{v}$ kar največji meri izrabi dialoge in stripe, ki vsebujejo veliko uporabnih jezikovnih sredstev iz vsakdanje komunikacije $\mathrm{v}$ italijanščini (za razvijanje ustnega sporazumevanja po besedilnih modelih), ter visok motivacijski naboj, ki ga nudi muzikalična plat slušnih besedil.

V 4. razredu bi učitelj že lahko dodajal v pouk tudi besedila, ki vsebujejo slovnične strukture, ki se jih uporablja za pripovedovanje o preteklosti, prihodnosti in pogojnosti, vendar naj bi te ostale na implicitni ravni. V 5. razredu pa bi učitelj že lahko dodajal tudi nadaljnja besedila, ki vsebujejo slovnične strukture, ki se jih uporablja za pripovedovanje o preteklosti, prihodnosti in pogojnosti, vendar naj bi te ne ostale zgolj na implicitni ravni: ob primerni pedagoški slovnici naj učenci le dobijo tudi kratko in jedrnato slovnično pojasnilo.

Učbenik Grandi amici 1, 2, 3 je glede na Učni načrt usklajen z učnimi cilji za poučevanje italijanščine kot drugega jezika v 3., 4, in 5. razredu osnovne šole $\mathrm{z}$ italijanščino kot jezikom okolja. Zasnovan je skladno $\mathrm{z}$ pedagoško-didaktičnim spoznanji sodobne glotodidaktike, jezikovno je ustrezen, didaktično-metodično primerno zasnovan in oblikovno dovršen.

\author{
Darja Mertelj \\ Oddelek za romanske jezike \\ in književnosti \\ Filozofska fakulteta v Ljubljani
}

